\title{
Disconnect between parents' values for saving and actual savings behavior: Impact on children's education and financial decision-making
}

\author{
Diane Masuo ${ }^{1}{ }^{*}$, Michael Cheang ${ }^{2}$ \\ 1, 2 University of Hawai'i at Manoa, Honolulu, HI
}

\section{Keywords \\ Savings attitudes \\ Savings behavior \\ Financial decision making \\ Children's savings}

Received: 18 October 2017

Accepted: 24 November 2017

Published: 4 December 2017

\begin{abstract}
The objective of this study was to determine the feasibility of encouraging low-income parents to save for their children through a savings program offered in public schools. Since children's savings have long-lasting effects on college entrance and graduation rates, this paper looked specifically at the relationship between parents' savings values and whether they opened a savings account for their child. A convenience sampling design was used to recruit schools for this study. A total of 17 public elementary schools was recruited for this study with a sample of 1,764 respondents. The survey instrument used in this study consisted of 13 four-point Likert scaled items and 13 other short answers, multiple-choice or fill-in-the-blank questions. Covariates including individual characteristics of the parents and household characteristics were examined to see if they were significantly related to whether or not a child's savings account was opened. Implications of the findings concerning early intervention work with parents are discussed, as are recommendations for future research with low-income families.
\end{abstract}

(c) 2017 The Author(s). Published by TAF Publishing.

\section{INTRODUCTION}

Background

Financial well-being eludes many. Why? Because individuals lack the personal attributes of financial knowledge and critical thinking skills that are prerequisite to being able to make informed financial decisions (Consumer Financial Protection Bureau, 2015; Manager, 2017; Organization for Economic Co-operation and Development, 2013). In order to achieve high levels of financial well-being as an adult, individuals need to be financially socialized at an early age. Developmental psychologists report that the ability to stay focused on long-term goals and learning how to process information develop rapidly in children during the first five years of life. Researchers have observed that when children exhibit high levels of these critical skills, they are better able to weather the negative effects of living in poverty, for example.

Financial socialization of children begins with parents, since parents are the first-line teachers at home (Danes and Haberman, 2007; Danes, Sharon, Catherine and Laurie, 1999; Gudmunson and Danes, 2011). Despite this fact, examination of the role that parents play in developing the financial well-being of children versus young adults, has been limited, especially among low income households.

Savings, in general provide opportunities for children to accumulate the knowledge and skills they will need in the workplace and will enable them to make responsible decisions in the marketplace that directly impact the quality of their lives (Elliott, Jung and

\footnotetext{
${ }^{*}$ Corresponding author: Diane Masuo

†Email: masuo@hawaii.edu
} 
Friedline, 2010; Elliott, 2013). When savings were larger and targeted for school, and when family incomes were higher, college attendance and graduation percentages increased (Elliott, 2013). Also, children with college savings are more likely to get better grades and complete more years of education (Elliott and Beverly, 2011).

\section{LITERATURE REVIEW}

Financial (II) Literacy of the Young Adult American

In order to have financial well-being, one needs to have the financial knowledge, appropriate financial attitudes, and sound financial practices (Totenhagen et al., 2015). However, previous studies indicate that high school and college students in the U.S. lack financial knowledge and skills (Jorgensen and Salva, 2010; Jacolbia, 2016; Mandell, 2009), and efforts in financial education to address these deficits have mixed results (Peng, Bartholomae, Fox and Cravener, 2007; Yates and Ward, 2011).

\section{Financial Socialization of Children}

In a world that is becoming increasingly financially complex, it is important to socialize children and teach them smart money management skills earlier in life. Parents are the main agents of socialization for elementary and middle school children (Ivan and Dickson, 2008; Edano, Punzalan and Tumutod, 2017), and parents' influence on their children's understanding of money management begins early on in life. For example, children as young as five years old are capable of understanding economic concepts, and have knowledge and attitudes about their role as consumers before they even start school (Kuhlmann, 1983; Fatimah, Norhafizah, Noryanti, Rozieana and Hassan, 2015; Webley and Nyhus, 2006).

Factors Associated with Personal Financial Management

Personal financial management occurs when an individual considers his/her needs versus wants and applies skills to make financial decisions (Ozmete and Hira, 2011). This decision making process is influenced by cognitive, social and psychological factors. Cognitive factors include financial knowledge, social factors related to parental influence, and psychological factors such as self-discipline, thoroughness (e.g., conscientiousness) and perceived control over outcomes (e.g., locus of control) (Bandura, 2001; Johnson and Sherraden 2007; Perry and Morris, 2005; Rimer and Glanz, 2005; Shim and Serido, 2011).

Recent research findings question the assumption that improved financial knowledge alone results in more effective financial decisions (Chen and Volpe, 1998; Hilgert, Hogarth and Beverly, 2003; Lusardi and Mitchell, 2007; Robb and Woodyard, 2011; Tang, Baker and Peter, 2015). Rather, these studies identified the influence of social (e.g., parental influence) and psychological factors (e.g., self-control, thoroughness, locus of control) on an individual's ability to make effective financial decisions including cash flow, credit and saving.

Purpose and Research Objectives

Since basic savings or saving for college begins with action by parents, several objectives were identified for this study of low-income households. They included an examination of: 1) The parents' stated savings values (It is important for my child to start saving early in life), 2) the extent to which actual savings behavior occurred (I have opened a savings account in my child's name, 3) the reasons why parents did not open a savings account in a child's name, and 4) the covariates that were related to whether or not a child's savings account was opened.

\section{Research Hypotheses}

Four hypotheses were identified relative to examining the covariates associated with whether or not parents opened a child's savings account. They included: 
H1: There is a positive relationship between parent's age and whether a savings account was opened in a child's name.

H2: There is a positive relationship between household income and whether a savings account was opened in a child's name.

H3: There is a positive relationship between number of children in the family and whether a savings account was opened in a child's name.

H4: There is a positive relationship between family type and whether a savings account was opened in a child's name and reasons for not opening a child's savings account.

\section{METHODOLOGY}

The survey instrument used in this study consisted of 13 four-point Likert scaled items and 13 other short answer, multiple choice or fill-in-the-blanks questions. The survey collected background information about the parent participants, their values/attitudes towards saving and whether or not they opened a savings account in their child's name.

A convenience sampling design was used to recruit schools for this study. A total of 17 public elementary schools was recruited for this study with a sample of 1,764 respondents. The response rate of this survey questionnaire is 27 percent.

First, schools located in low-income districts were identified by whether or not 50 percent or more of a school's student population qualified for a school lunch subsidy program. If the school met the definition, then that school was identified as having students living in a low-income household. The unit of analysis for this study was the household in which the child resides.

RESULTS

A total of 1,764 parents completed and returned the survey questionnaire. Due to nonresponse on some survey questions, analyses were based on 1,645 cases. The median age of the parents interviewed was 37 years. They identified their ethnicity as Asian (40.6\%), Native Hawaiian (23.1\%), White (9.3\%), Pacific Islander (8.6\%), African American (.7\%) or other $(5.2 \%)$. The predominant family type was dual parent household $(N=1,198$, $78.9 \%)$ and the single parent household makes up 26.1\% $(N=423)$ of the sample. The median household annual income was $\$ 45,000$. More than two out of every three families lived in a rural community on an island other than Oahu, where the state's capitol is located.

Relationship of Parents' Savings Values and Actual Savings Behavior

When savings values of the parents' (Important for child to save early) were compared with actual savings behavior (whether or not a savings account was opened in my child's name) significant differences were found ( $p<.0001$, see Table 1$)$.

TABLE 1. Comparison by saving for child versus non-saving: Disconnect between parents' actual savings behavior versus savings values

\begin{tabular}{|c|c|c|c|c|c|c|c|c|c|}
\hline & \multicolumn{2}{|c|}{ All } & \multicolumn{6}{|c|}{ Saving for Child } & \multirow[t]{3}{*}{$p$ value $^{1}$} \\
\hline & & & \multicolumn{2}{|c|}{ Yes } & \multicolumn{2}{|l|}{ No } & \multicolumn{2}{|c|}{ Missing } & \\
\hline & Mean & Std & Mean & Std & Mean & Std & Mean & Std & \\
\hline $\begin{array}{l}\text { Important for child to } \\
\text { start saving early in life }\end{array}$ & 1.3 & 0.5 & 1.2 & 0.5 & 1.4 & 0.5 & 1.7 & 0.7 & $<.0001$ \\
\hline
\end{tabular}

When asked how strongly they valued early savings for their children, on a Likert-scaled

4-point scale where 1 = strongly agree and 4 = strongly disagree, $99.0 \%$ of the parents 
said they either "strongly agreed" or "agreed" with the statement (see Table 2). However, despite agreeing that it was important for their child to save regularly and early in life, only $42.9 \%$ of these same parents actually opened a savings account in their child's name. Some reasons for this observed inconsistency (or disconnect) between savings values and actual savings behavior are listed in Table 3.

Among the reasons parents listed for not opening a savings account for a child were: lack of funds (34.6\%) and never got to it (19.6\%). Of the parents who opened a children's savings account, the median amount was $\$ 25$ (see Table 3).

TABLE 2 . Disconnect between parents' savings value versus savings behavior

\begin{tabular}{lcccc}
\hline \hline & \multicolumn{3}{c}{ Parent's savings value (It is important for child to start saving money regularly early in life) } \\
\cline { 2 - 4 } & Strongly Agree (1) & Agree (2) & Disagree (3) & Strongly Disagree (4) \\
\hline Parent's savings behavior (Child & $\%$ & $\%$ & $\%$ & $\%$ \\
has savings account his/her name) & & & & 0.0 \\
Yes (1) $42.9 \%$ & 78.8 & 20.2 & 1.0 & 0.8 \\
No (2) $55.1 \%$ & 64.1 & 32.8 & 2.3 & \\
\hline \hline
\end{tabular}

TABLE 3 . Reasons for not saving for child and dollar amount saved

\begin{tabular}{lcc}
\hline \hline Do not have saving for child $(N=995)$ & & \\
\hline Reasons for not having savings & $N$ & $\%$ \\
Cannot afford & 344 & 34.6 \\
Just never got to it & 195 & 19.6 \\
Other & 133 & 13.4 \\
Think that we have time in & 95 & 9.5 \\
the future to do this & & \\
My child is too young to start & 77 & 7.7 \\
Never thought of it & 54 & 5.4 \\
Too inconvenient to do so & 25 & 2.5 \\
Having saving for child $(N=734)^{1}$ & & \\
Median amount of saving in U.S. dollar & & 25.0 \\
Quartile 1 & & 20.0 \\
Quartile 3 & & 60.0 \\
Inter-quartile range & 40.0 \\
Number of valid response & 493 \\
Missing & \\
\hline 1. Median and interquartile range & 241 \\
\hline
\end{tabular}

\section{Research Hypotheses}

Table 4 summarizes the characteristics of the parents and their households and presents findings relative to the four hypotheses that were tested.

H1: There is a positive relationship between parent's age and whether a savings account was opened in a child's name. 
TABLE 4 . Characteristics of parents of elementary school households

\begin{tabular}{|c|c|c|c|c|c|c|c|c|c|c|}
\hline & & \multirow{2}{*}{\multicolumn{2}{|c|}{ All }} & \multicolumn{6}{|c|}{ Saving for Child } & \multirow[t]{3}{*}{$p$ value $^{1}$} \\
\hline & & & & \multicolumn{2}{|c|}{ Yes } & \multicolumn{2}{|c|}{ No } & \multicolumn{2}{|c|}{ Missing } & \\
\hline & & $N$ & $\%$ & $N$ & $\%$ & $N$ & $\%$ & $N$ & $\%$ & \\
\hline Number of parents & & 1764 & 100.0 & 734 & 100.0 & 995 & 100.0 & 35 & 100.0 & \\
\hline Household income ${ }^{2}$ & & 45000 & 44000 & 55000 & 45000 & 35000 & 37500 & 60000 & 0 & $<0.0001$ \\
\hline Number of children ${ }^{2}$ & & 2 & 1 & 2 & 1 & 3 & 1 & 3 & 2 & $<0.0001$ \\
\hline \multirow[t]{2}{*}{ Area of resident } & & & & & & & & & & 0.10 \\
\hline & Urban & 583 & 33.0 & 231 & 31.5 & 351 & 35.3 & 1 & 2.9 & \\
\hline \multirow[t]{4}{*}{ Family type } & & & & & & & & & & $<0.0001$ \\
\hline & Single parent & 423 & 24.0 & 158 & 21.5 & 259 & 26.0 & 6 & 17.1 & \\
\hline & Dual parents & 1198 & 67.9 & 543 & 74.0 & 648 & 65.1 & 7 & 20.0 & \\
\hline & Missing & 143 & 8.1 & 33 & 4.5 & 88 & 8.8 & 22 & 62.9 & \\
\hline \multirow[t]{2}{*}{ Family role } & & & & & & & & & & 0.0003 \\
\hline & Missing & 87 & 4.9 & 15 & 2.0 & 49 & 4.9 & 23 & 65.7 & \\
\hline \multirow[t]{9}{*}{ Ethnicity } & & & & & & & & & & 0.03 \\
\hline & American Indian/Alaska Native & 17 & 1.0 & 8 & 1.1 & 9 & 0.9 & 0 & 0.0 & \\
\hline & Asian & 717 & 40.6 & 336 & 45.8 & 377 & 37.9 & 4 & 11.4 & \\
\hline & African American & 13 & 0.7 & 3 & 0.4 & 10 & 1.0 & 0 & 0.0 & \\
\hline & Native Hawaiian & 407 & 23.1 & 149 & 20.3 & 254 & 25.5 & 4 & 11.4 & \\
\hline & Pacific Islander & 151 & 8.6 & 56 & 7.6 & 94 & 9.4 & 1 & 2.9 & \\
\hline & White & 164 & 9.3 & 70 & 9.5 & 94 & 9.4 & 0 & 0.0 & \\
\hline & Other & 91 & 5.2 & 40 & 5.4 & 48 & 4.8 & 3 & 8.6 & \\
\hline & Missing & 204 & 11.6 & 72 & 9.8 & 109 & 11.0 & 23 & 65.7 & \\
\hline
\end{tabular}

1. $p$-values derived from chi-square and t-statistic

2. Median and inter-quartile range

Age of parents was not significantly related to whether or not a children's savings account was opened.

H2: There is a positive relationship between household income and whether a savings account was opened in a child's name.

Higher annual household income was significantly related to having a children's savings account $(p<.0001)$. This finding is supported in the literature on children's savings accounts (Elliott 2013; Elliott and Beverly 2011; Elliott et al., 2012).

In families with a child's savings account, the median household income was $\$ 55,000$ compared to $\$ 35,000$ in households with no child's savings account.

H3: There is a positive relationship between number of children in the family and whether a savings account was opened in a child's name.

The more children in the family, the more likely it was that there was no children's savings account opened. This finding was significant $(p<.0001)$. In families with a child's savings account, the median number of children present was 2, compared to 3 in families with no child's savings account.

H4: There is a positive relationship between family type and whether a savings account was opened in a child's name.

Dual parent families were more likely to have a children's savings account than single parent families. This finding was significant $(p<.0001)$. When comparing whether or not a child's savings account was opened by the household type, only $21.5 \%$ of singleparent households had a child's savings account, compared to $74.0 \%$ in dual-parent house- 
holds. Among the households that did not have a child's savings account, a larger percent of single-parent households did not open a child's savings account compared to the dualparent households (see Table 4).

As stated earlier, of the parents who "agreed" or "strongly agreed" that it is important for a child to start saving money regularly in life, only $42.9 \%$ actually opened a savings account for their child (see Table 2). This disconnect can be viewed as an opportunity for intervention by practitioners who can work to remove barriers to opening children's savings accounts.

Several existing commercial bank policies may be preventing low income families from opening a savings account for their child. First, commercial banks often require a large (for low income clients) initial deposit amount (typically USA \$100) in order for a savings account to be opened. Second, many banks also require that a minimum balance (of USA $\$ 300$ ) be maintained to keep the savings account active, and thirdly, once the account becomes inactive, the account will incur monthly fees or be closed. In comparison, federal credit unions often require only USA $\$ 25$ or less to open a savings account. Therefore, if federal credit unions actively recruit low income families as customers, they will be making an investment with long-term positive benefits for the parents and children, in particular, who live in the communities they serve.

\section{LIMITATIONS AND RECOMMENDATIONS}

Clearly, this study is not without limitations. The use of a convenience sample makes it not possible to generalize the findings to a larger population. Given the advice of a school principal that the survey should not be more than one sheet of paper otherwise the parents will not respond to the survey, many important questions were not included in the survey. In addition, there may be confounding factors that may explain why parents who say they value saving regularly for themselves have not opened a savings account for their child, such as situations where the parents work at multiple jobs and have no time to open a savings account or when parents avoid making financial transactions because of their limited English-speaking skills.

Since the initial objective of this study was to determine the feasibility of encouraging lowincome parents to save for their children through a savings program offered in the public schools, the survey instrument developed for this project did not include some important gender-based financial literacy issues such as whether the financial socialization process differs for male versus female children and how these differences impact the financial decision making abilities of boys versus girls later in life.

Future research should examine these issues and be expanded to include low-income children and parents who come from understudied populations such as native Hawaiian and Pacific Islanders. Future research may also benefit from the addition of a qualitative component that explores the roadblocks to opening a savings account in a child's name. Findings can then inform practice as practitioners are better able to deliver more individualized financial help based on their clients' gender, ethnicity and socio-economic background. 


\section{REFERENCES}

Bandura, Albert. 1999. Social cognitive theory: An agentic perspective. Asian Journal of Social Psychology 2, no. 1: 21-41. DOI: $10.1111 / 1467-839 x .00024$

Boelens, R., De Wever, B. and Voet, M. 2017. Four key challenges to the design of blended learning: A systematic literature review. Educational Research Review, 22: 1-18.

Ivan, Beutler, and Lori Dickson. 2008. Consumer economic socialization. In Handbook of consumer finance research, ed. Jing J. Xiao. New York, NY: Springer.

Chen, Haiyang, and Ronald P. Volpe. 1998. An analysis of personal financial literacy among college students. Financial Services Review 7, no. 2: 107-128. D0I: 10.1016/s1057-0810(99)80006-7

Consumer Financial Protection Bureau. 2015. 2015 consumer response annual report.

URL: https://bit.ly/2vn3h5n (accessed on February 25, 2016)

Danes, Sharon M., Catherine Huddleston-Casas, and Laurie Boyce. 1999. Financial planning curriculum for teens: Impact evaluation. Journal of Financial Counseling and Planning 10, no. 1: 26-34. DOI: 10.1007/978-1-4419-6908-8_3

Danes, Sharon, and Heather Haberman. 2007. Teen financial knowledge, self-efficacy, and behavior: A gendered view.

Journal of Financial Counseling and Planning 18, no. 2: 1-13. D0I: 10.1111/j.0197-6664.2005.00010.x

Edano, Domingo C, Punzalan Edna Marie D, and Tumutod Natty L. 2017. Transformational leadership styles of public

ele- mentary school principals in relation to school social organizational factors in region III, Philippines. International Journal of Humanities, Arts and Social Sciences 3, no. 3: 113-121. D0I: 10.20469/ijhss.3.20003-3

Elliott, William. 2013. Small-dollar children's savings accounts and college outcomes. Center for Social Development Working paper No. 13-05, Washington University, St. Louis, MO.

Elliott, William, and Sondra Beverly. 2011. Staying on course: The effects of savings and assets on the college progress of young adults. American Journal of Education 117, no. 3: 343-374. DOI: 10.1086/659211

Elliott, William, Hyunzee Jung, and Terri Friedline. 2010. Math achievement and children's savings: Implications for child development accounts. Journal of Family and Economic Issues 31, no. 2: 171-184. DOI: 10.1007/s10834-010-9185-4

Elliott, William, Monique Constance-Huggins, and Hyun-A. Song. 2013. Improving college progress among Low-to Moderate Income (LMI) young adults: The role of assets. Journal of Family and Economic Issues 34, no. 4: 382-399.

DOI: $10.1007 / \mathrm{s} 10834-012-9341-0$

Gudmunson, Clinton G., and Sharon M. Danes. 2011. Family financial socialization: Theory and critical review. Journal of Family and Economic Issues 32, no. 4: 644-667. DoI: 10.1007/s10834-011-9275-y

Hilgert, Marianne A., Jeanne M. Hogarth, and Sondra G. Beverly. 2003. Household financial management: The connection between knowledge and behavior. Federal Reserve Bulletin 89, no. 4: 309-315.

Hubackova, S. and Semradova, I., 2016. Evaluation of blended learning. Procedia-Social and Behavioral Sciences, 217: 551-557.

Jacolbia, Rovelina B. 2016. Future educators' perceptions on technology and livelihood education status and development of work skills. Journal of Advances in Humanities and Social Sciences 2, no. 2: 85-91. D0I: 10.20474/jahss-2.2.3

Johnson, Elizabeth, and Margaret S. Sherraden. 2007. From financial literacy to financial capability among youth. Journal of Sociology and Social Welfare 34, no. 4: 119-125.

Jorgensen, Bryce L., and Jyoti Savla. Financial literacy of young adults: The importance of parental socialization. Family Relations 59, no. 4: 465-478. DOI: 10.1111/j.1741-3729.2010.00616.x

Kuhlmann, Eberhard. 1983. On the economic analysis of the information-seeking behaviour of consumers. Journal of Consumer Policy 6, no. 2: 231-237. DOI: 10.1007/bf00411383

Lusardi, Annamaria, and Olivia S. Mitchell. 2007. Baby boomer retirement security: The roles of planning, financial literacy, and housing wealth. Journal of Monetary Economics 54, no. 1: 205-224. DOI: 10.1016/j.jmoneco.2006.12.001

Manager, D. 2017. The aesthetic dimension of decision making: A case study of a German software company. International Journal of Humanities, Arts and Social Sciences 3, no. 5: 223-230. DOI: 10.20469/ijhss.3.20005-5

Mandell, L. 2009. The impact of financial education in high school and college on financial literacy and subsequent financial decision making. URL: https://bit.ly/2HMaX3S (accessed on January 13, 2017).

Organization for Economic Co-operation and Development. 2013. PISA 2012 assessment and analytical framework: ISSN: 2414-3111

DOI: $10.20474 /$ jahss-3.6.5 
Mathematics, reading, science, problem solving and financial literacy, OECD Publishing.

URL: https://bit.ly/2Ha9AyC (accessed on March 13, 2015).

Ozmete, Emine, and Tahira Hira. 2011. Conceptual analysis of behavioral theories/models: Application to financial behav- ior.

European Journal of Social Sciences 18, no. 3: 386-404. DOI: 10.4018/978-1-4666-7484-4.ch008

Peng, Tzu-Chin Martina, Suzanne Bartholomae, Jonathan J. Fox, and Garrett Cravener. 2007. The impact of personal finance education delivered in high school and college courses. Journal of Family and Economic Issues 28, no. 2: 265-284.

DOI: $10.1007 / \mathrm{s} 10834-007-9058-7$

Perry, Vanessa G., and Marlene D. Morris. 2005. Who is in control? The role of self-perception, knowledge, and income in explaining consumer financial behavior. Journal of Consumer Affairs 39, no. 2: 299-313.

DOI: $10.1111 / \mathrm{j} .1745-6606.2005 .00016 . \mathrm{x}$

Rimer, B., and Glanz K. 2005. Theory at a glance a guide for health promotion practice.

URL: https://bit.ly/2H8pbyJ (accessed on October 13, 2010).

Robb, Cliff A., and Ann Woodyard. 2011. Financial knowledge and best practice behavior. Journal of Financial Counseling and Planning 22, no. 1: 60-70. DOI: 10.4148/jft.v3i1.1453

Shim, S., and Serido J. 2011. Young adults' financial capability.

URL: https://bit.ly/2qL2rKq (accessed on February 26, 2014)

Siti Fatimah, A. Z., Norhafizah M. S., Noryanti M., Rozieana K., and Hassan, R. G. 2015. A study of students' performance in calculus and their attitudes toward the course using tripartite model. International Journal of Humanities, Arts and Social Sciences 1, no. 1: 30-35. DOI: 10.20469/ijhss.20005

Tang, Ning, Andrew Baker, and Paula C. Peter. 2015. Investigating the disconnect between financial knowledge and behav- ior: The role of parental influence and psychological characteristics in responsible financial behaviors among young adults. Journal of Consumer Affairs 49, no. 2: 376-406. D0I: 10.1111/joca.12069

Totenhagen, Casey J., Deborah M. Casper, Kelsey M. Faber, Leslie A. Bosch, Christine Bracamonte Wiggs, and Lynne M. Bor- den. 2015. Youth financial literacy: A review of key considerations and promising delivery methods. Journal of Family and Economic Issues 36, no. 2: 167-191. DOI: 10.1007/s10834-014-9397-0

Webley, Paul, and Ellen K. Nyhus. 2006. Parents' influence on children's future orientation and saving. Journal of Economic Psychology 27, no. 1: 140-164. D0I: 10.1016/j.joep.2005.06.016

Yates, Dan, and Chris Ward. 2011. Financial literacy: Examining the knowledge transfer of personal finance from high school to college to adulthood. American Journal of Business Education 4, no. 1: 65-75. DOI: 10.19030/ajbe.v4i1.1274 